\title{
SYSTEM SĄDOWNICTWA CYWILNEGO W JAPONII
}

\author{
Yuki HORIE, mgr \\ Instytut Językoznawstwa, Uniwersytet im. Adam Mickiewicza w Poznaniu \\ Al. Niepodległości 4, 61-874 Poznań \\ pupu@amu.edu.pl
}

\begin{abstract}
Abstrakt: W tym artykule zostały omówione organizację sądu w Japonii oraz porównanie z sądownictwem polskim, następnie szczegółowo przedstawiono japońską organizację sądową oraz osoby związane z działalnością sądów japońskich. W Japonii sądy zajmują się pięcioma rodzajami spraw według prawa japońskiego: cywilnymi; administracyjnymi; karnymi; rodzinnymi oraz dotyczącymi nieletnich. W ostatniej części została omówiona sprawa cywilna w Japonii, szczególnie rodzaje postępowań cywilnych, nazewnictwo stron procesowych, ważne terminy z zakresu procedur cywilnych oraz ogólny przebieg spraw cywilnych.
\end{abstract}

\section{CIVIL JUDICIARY SYSTEM IN JAPAN}

Abstract: In this article it is written about the organization of Japanese court and the comparison with Polish judiciary system, then each Japanese court and the persons who are involved in the trial is also presented in detail. In Japan, five types of cases are dealt with at the courts according to the Japanese law: civil case, administrative case, criminal case, family case and the case which is related with the juvenile. The last part of this article was devoted to about the civil case in Japan, especially about the overview of the civil procedure, naming of the parties and the important terms concerning the civil case.

Słowa kluczowe: sądownictwo w Japonii, sąd, prokurator, oskarżyciel, sędzia 


\section{Organizacja sądów}

W Japonii najwyższą instancją i tzw. sądem najwyższej rangi jest na mocy konstytucji 最高裁判所 saikō saibansho (sąd najwyższy). Sądami tzw. niższej rangi są 高等裁判所 kōtō saibansho (sąd krajowy, dosłownie: „sąd wysoki”), 地方裁判所 chihō saibansho (sąd okręgowy), 家庭裁判所 katei saibansho (sąd rodzinny) oraz 簡易裁判所 kan'i saibansho (sąd do spraw drobnych, dosłownie: „sąd uproszczony i przyspieszony”), sprawy zaś, którymi zajmują się, określone są przez prawo sądowe. W zakresie procedur sądowych, dla skutecznej realizacji zasad sprawiedliwego postępowania sądowego, obowiązuje zasada trójinstancyjności. Strona, która po wyroku sądu pierwszej instancji, jest zeń niezadowolona, może odwołać się do sądu drugiej instancji. To odwołanie nazywa się 控訴 kōso. W przypadku niezadowolenia z wyroku sądu drugiej instancji, może odwołać się do sądu wyższej, trzeciej instancji. To odwołanie nazywa się 上告 jōkoku. Kōso i jōkoku określa się zbiorczo jako 上訴 jōso (apelacje). Jedynie w przypadku spraw dotyczących nieletnich oraz rodzinnych stosuje się termin 抗告 kōkoku, ,sprzeciw”.

Poniższe wykresy pokazują strukturę sadownictwa japońskiego i polskiego.

\subsection{Japoński system sądowy}

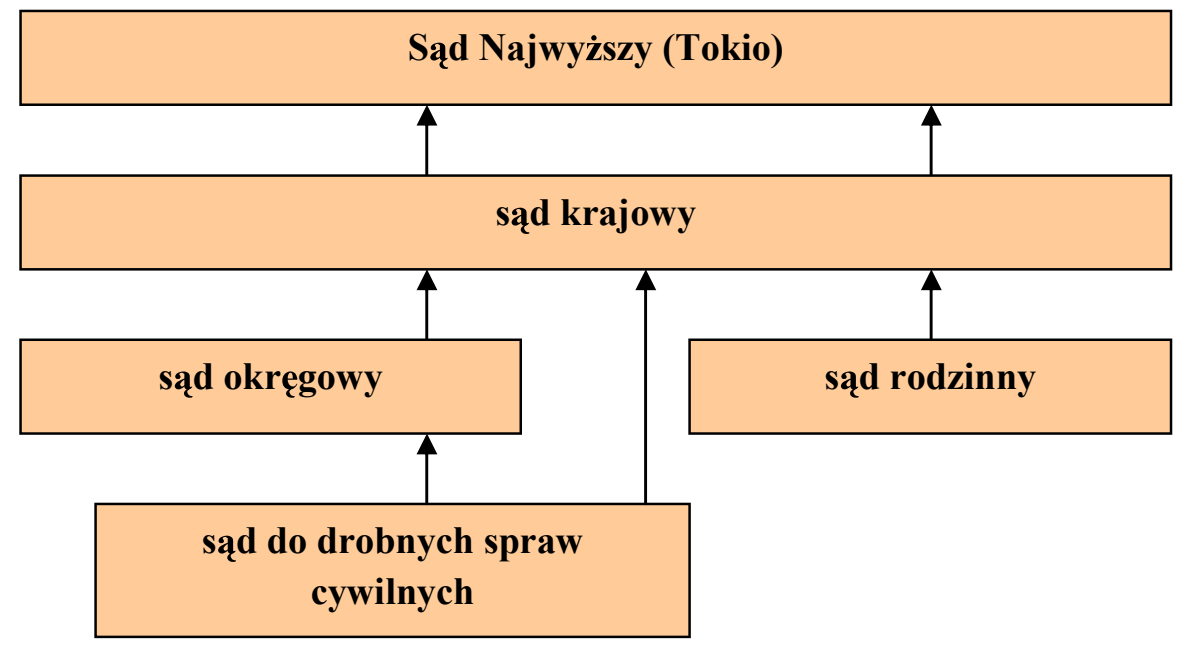




\subsection{Polski system sądowy}

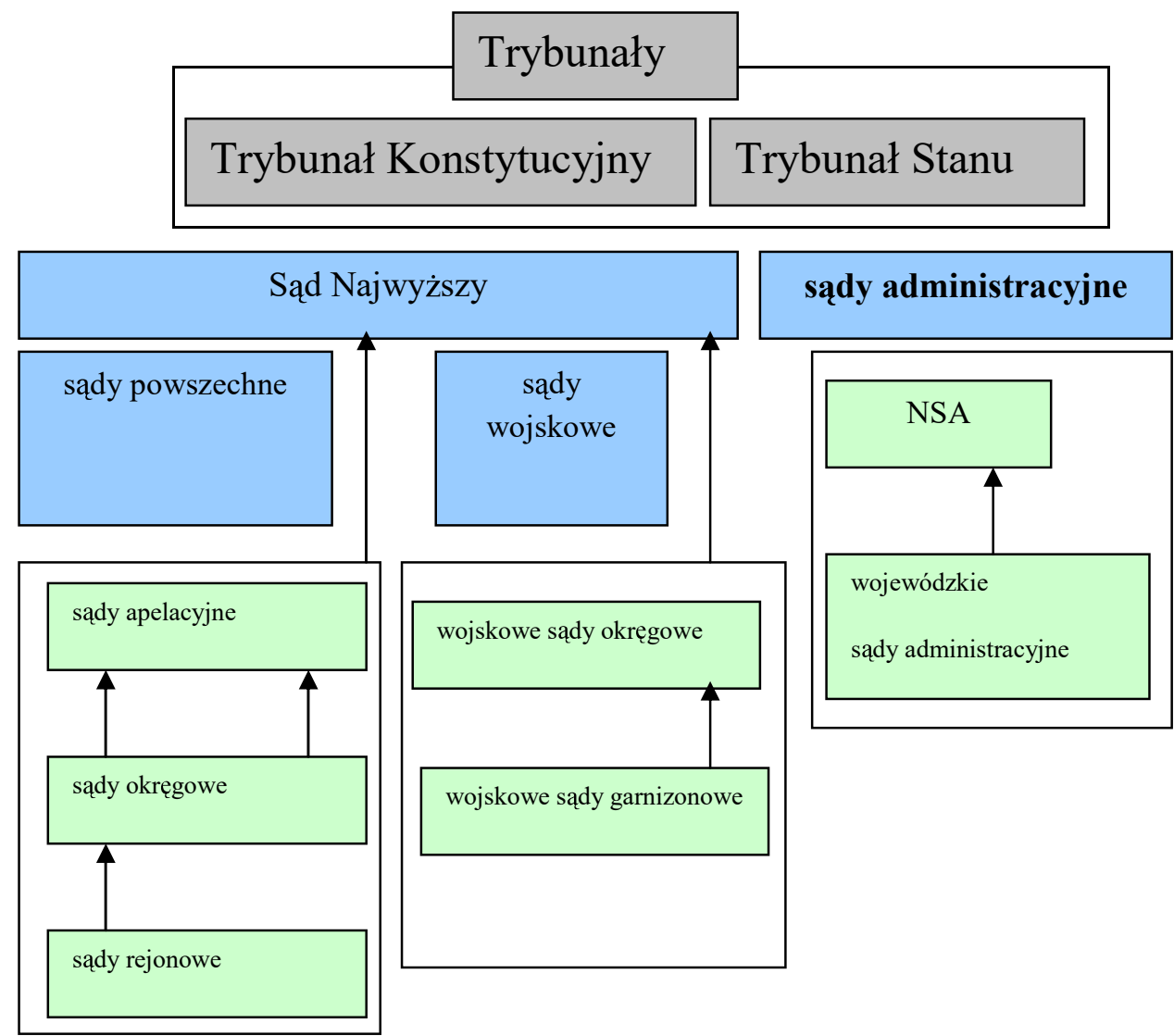

Jak widać na pierwszy rzut oka, struktura sądownictwa japońskiego jest prostsza niż sądownictwa polskiego. Po pierwsze w Polsce w organach władzy sądowniczej poza sądami jako organami wymiaru sprawiedliwości istnieją dwa trybunały (jap. 法廷 hōtei). Pierwszy, Trybunał Konstytucyjny (jap. 憲法法廷 Kenpō hōtei), orzeka zgodność ustaw, przepisów oraz ratyfikowanych umów międzynarodowych z konstytucją. Drugi, Trybunał Stanu (jap. 国家法廷 Kokka hōtei), jest właściwy dla osądzania działań podejmowanych w trakcie piastowania funkcji przez najwyższych urzędników państwa: prezydenta, premiera, ministrów, prezesa NBP, prezesa NIK, szefa Sztabu Generalnego Wojska Polskiego. W Japonii zgodność prawa z konstytucją należy do jurysdykcji Sądu Najwyższego i nie ma tego rodzaju organu jak polskie trybunały. Japoński termin stosowany jako thumaczenie słowa „trybunał” oznacza zwykle „salę rozpraw”. 
Ponadto w Polsce poza sądami powszechnymi są również sądy wojskowe i administracyjne, w Japonii zaś, zgodnie z Art. 75 Par. 2 konstytucji, nie można powołać do życia organu wymiaru sprawiedliwości nienależącego do struktury podporządkowanej Sądowi Najwyższemu. Stąd sprawy administracyjne poddane są podobnemu biegowi jak sprawy cywilne i karne. Wyjątkowo w kilku rodzajach spraw przewód przeprowadzany jest $\mathrm{w}$ innych instytucjach niż sądy powszechne. Pierwszy rodzaj to sprawy dyscyplinarne sędziów, rozpatrywane przez połączone izby parlamentu. Drugi rodzaj spraw to kwestie związane $\mathrm{z}$ ewentualnym naruszeniem przepisów prawa dotyczących sprawowania funkcji parlamentarzysty. Wówczas sędziami są koledzy danego parlamentarzysty z tej samej izby (Izby Radców - izba wyższa; Izby Reprezentantów izba niższa).

Ponadto cechą szczególną organizacji sądownictwa japońskiego są sądy rodzinne. W Polsce sąd rodzinny jest wydziałem sądu rejonowego, w Japonii zaś jest niezależnym organem wymiaru sprawiedliwości. Sąd ten jest właściwy dla spraw rodzinnych, mediacji rodzinnych, spraw dotyczących osobowego statusu prawnego, np. rozwodów, spraw dotyczących opieki nad nieletnimi oraz jako pierwsza instancja w sprawach karnych związanych z tzw. przestępstwami społecznymi (jap. 福祉犯罪 fukushi hanzai) w rozumieniu Art. 37 Par. 1 Prawa o nieletnich (jap. 少年法 shōnen hō). Innymi słowy sąd ten zajmuje się sprawami różniącymi się od innych pod względem konieczności możliwie poufnego rozwiązania sporu, jak np. w sprawach dotyczących osobistych problemów członków rodziny lub przestępstw nieletnich. Polski wydział rodzinny i nieletnich sądu rejonowego zajmuje się głównie przestępstwami społecznymi nieletnich oraz np. leczeniem osób uzależnionych od alkoholu, sprawy zaś takie jak rozwody pozostają we właściwości wydziału cywilnego.

\subsection{Zasady ogólne}

W przeciwieństwie do „przynajmniej dwuinstancyjności” w prawie polskim, w Japonii zasadą jest trójinstancyjność. Celem japońskiego prawodawcy było danie możliwości stronom dalszego dochodzenia swych roszczeń aż do trzeciej instancji zgodnie z przyświecającą mu intencją przywiązywania dużej wagi do stanowiska stron występujących przed sądem. W Polsce celem nadrzędnym jest wyraźne określenie, która ze stron ma rację, a która nie, oraz właściwe przeprowadzenie procesu - stąd przynajmniej dwuinstancyjność.

W przeciwieństwie do prawa polskiego, z zasady przewidującego, jeżeli sąd nie zarządził inaczej, toczenie się rozpraw przy drzwiach otwartych oprócz spraw rozwodowych, prawo japońskie przewiduje zamknięte posiedzenia sądu w przypadku spraw dotyczących małżeństw oraz przestępstw nieletnich toczonych przed sądem rodzinnym za wyjątkiem toczących się przed sądem sporów między stronami. Ma to na celu możliwie poufne rozpatrzenie tego typu spraw. 


\section{Sądy poszczególnych instancji w Japonii}

\section{1. 最高裁判所 Sąd Najwyższy}

Zgodnie z konstytucją Sąd Najwyższy jest jedynym najwyższym organem wymiaru sprawiedliwości i składa się z przewodniczącego oraz czternastu sędziów. Rozprawy odbywają się przed tzw. wielkim trybunałem, składającym się ze wszystkich piętnastu sędziów, lub przed trzema tzw. małymi trybunałami, po pięciu sędziów w każdym. Na co dzień Sąd Najwyższy zajmuje się rozpatrywaniem spraw sądowych oraz sprawami związanymi z funkcjonowaniem wymiaru sprawiedliwości. Te pierwsze to zasadniczo rozpatrywanie apelacji od wyroków sądów krajowych. Zazwyczaj rozpatrywanie spraw odbywa się poprzez analizę dokumentacji. Sprawa rozpatrywana jest przed małym trybunałem, jeżeli jednak w grę wchodzi zgodność ustaw, rozporządzeń i przepisów z konstytucją, wówczas właściwy jest wielki trybunał. Obowiązki Sądu Najwyższego związane $\mathrm{z}$ funkcjonowaniem władzy sądowniczej to uchwalanie przez sąd ważnych przepisów dotyczących wewnętrznej organizacji i funkcjonowania wymiaru sprawiedliwości. Przy przyjmowaniu odpowiednich przepisów zawiąuje się komisja z udziałem sędziów, adwokatów, prokuratorów oraz uczonych i osób posiadających stosowną wiedzę i doświadczenie, która przyjmuje projekt przepisów, poddawany następnie obradom kolegium sędziów Sądu Najwyższego i przezeń przyjmowany. Do tej pory Sąd Najwyższy zatwierdził ponad sto takich przepisów.

\section{2. 高等裁判所 Sąd krajowy}

Sądy krajowe urzędują w ośmiu wielkich miastach Japonii (Tokio, Osaka, Nagoya, Hiroshima, Fukuoka, Sendai, Sapporo i Takamatsu), ponadto w sześciu innych miastach znajdują się ich delegatury. Każdy sąd składa się z przewodniczącego i sędziów. Ponadto specjalną delegaturą jest sąd ds. własności intelektualnej (jap. 知的財産高等裁判所 chitekizaisan kōtō saibansho) przy Sądzie Najwyższym w Tokio. Sąd ds. własności intelektualnej rozpatruje sprawy odwołań od wyroków sąów okręgowych w sprawach dotyczących praw patentowych oraz sprawy dotyczące tzw. prawa do unieważnienia (jap. 取消権 torikeshiken) wobec orzeczeń Urzędu Patentowego.

Sądy krajowe są właściwe dla rozpatrywania apelacji od wyroków sądów okręgowych i rodzinnych, odwołań od wyroków w sprawach karnych sądów do spraw drobnych oraz apelacji od wyroków drugiej instancji sądów okręgowych w sprawach cywilnych. Z zasady sądy krajowe obradują w składach trzyosobowych. 


\section{3. 地方裁判所 Sąd okręgowy}

W całej Japonii urzęduje pięćdziesiąt sądów okręgowych. Ich jurysdykcji poddany jest cały obszar prefektury, w której się znajdują ${ }^{68}$, ponadto istnieją 203 delegatury sądów okręgowych.

Z zasady sąd okręgowy jest sądem pierwszej instancji, posiadając ponadto uprawnienia do rozpatrywania odwołań od wyroków sądów do spraw drobnych. Sądy okręgowe obradująjednoosobowo lub, jeśli zajdzie taka potrzeba, trzyosobowo.

\section{4. 家庭裁判所 Sąd rodzinny}

Sąd rodzinny i jego delegatury mieszczą się razem z sądami okręgowymi i jego delegaturami; ponadto tworzy się dodatkowe delegatury w tych miejscach, gdzie jest to potrzebne. Sąd rodzinny jest sądem, który ma rozpatrywać spory dotyczące prywatnych spraw rodzinnych nie na drodze procesu, ale poprzez procedurę zamkniętą. Ponadto ponieważ wymierzenie kary na sali sądowej niepełnoletniemu, który popełnił czyn niezgodny z prawem, może wywrzeć na niego niekorzystny wpływ, niepełnoletni, którzy rokują nadzieje poprawy, zostają osądzeni i pouczeni w procedurze zamkniętej. Innymi słowy przywiązuje się wielką wagę nie do tego, aby określić czy dany niepełnoletni postapił źle lub dobrze, ale by poznać przyczyny leżące u podstaw jego postępowania i zastanowić się, w jaki sposób można wpłynąć na powrót niepełnoletniego do właściwej postawy i zachowania.

\section{5. 簡易裁判所 Sąd do spraw drobnych}

W Japonii działa 438 sądów do spraw drobnych, w których orzeka jeden sędzia. Sądy te są pierwszą instancją $\mathrm{w}$ sprawach cywilnych, w których przedmiot roszczenia nie przekracza 1400000 jenów oraz w sprawach karnych, w których grożą niskie kary, jak sprawy kradzieży lub zawłaszczenia oraz sprawy zagrożone karami grzywny i niższymi. Sąd ten może orzec wyłącznie kary grzywny i niższe oraz karę pozbawienia wolności do trzech lat. Jeżeli w sprawie grożą wyższe kary, jest ona automatycznie przekazywana do sądu okręgowego. W sądach do spraw drobnych działa system mediacji mający na celu ugodowe rozwiązywanie spraw. Procedura mediacyjna jest darmowa i jest rozpatrywana przez członków zespołu mediacyjnego, stąd nie towarzyszy mu napięta atmosfera sali sądowej.

\footnotetext{
${ }^{68}$ wyjątkiem jest prefektura Hokkaidō, która ze względu na duży obszar ma cztery sądy okręgowe
} 


\section{Osoby związane z działalnością sądów japońskich}

\section{1. 裁判官 saibankan (Sędzia)}

Jak mówi konstytucja: „wszyscy sędziowie są niezawiśli, kierują się w orzekaniu swoim sumieniem, a związani są jedynie niniejszą Konstytucją oraz ustawami" ${ }^{69}$. Jeżeli chodzi o stanowiska sędziowskie, w Sądzie Najwyższym są to przewodniczący sądu najwyższego oraz sędziowie sądu najwyższego, w sądach krajowych przewodniczący sądu krajowego oraz sędziowie sądu krajowego, w innych sądach sędziowie. Ponadto osoba mianowana na sędziego w ciagu pierwszych dziesięciu lat po mianowaniu nosi tytuł aplikanta sędziowskiego (jap. 判事補. hanjiho). Zgodnie z Prawem sądowym (jap. 裁判所法 saibansho hō ) (Art. 27 Par. 1) kandydat sędziowski nie może orzekać samodzielnie, dlatego kandydaci sędziowscy uczestniczą tylko w sprawach, w których orzeka kolegium sędziowskie. Jednakże kandydaci sędziowscy, którzy mają więcej niż pięć lat doświadczenia i otrzymali specjalne pozwolenie od Sądu Najwyższego mogą w trybie wyjątkowym orzekać samodzielnie. Przewodniczący Sądu Najwyższego jest powołany przez rząd i mianowany przez cesarza (Konstytucja Japonii Art. 6 Par. 2, Prawo sądowe Art. 39 Par. 1). Sędziowie Sądu Najwyższego są mianowani przez rząd i zatwierdzani przez cesarza (Konstytucja Japonii Art. 79 Par. 1, Prawo sądowe Art. 39 Par. 2, 3). Sędziowie Sądu Najwyższego są mianowani spośród ponad czterdziestoletnich prawników o dużej wiedzy i doświadczeniu, dziesięciu zaś spośród sędziów musi spełniać następujące warunki: 1. ponaddziesięcioletnie sprawowanie funkcji sędziego (lub prezesa sądu krajowego); 2. ponaddwudziestoletnie sprawowanie funkcji prezesa sądu krajowego, sędziego, sędziego sądu do spraw drobnych, prokuratora, adwokata, profesora wydziału prawa (Prawo sądowe Art. 41). Sędziowie Sądu Najwyższego nie są kadencyjni (jednakże, jak mówi konstytucja Art. 79, podlegają kontroli narodu co dziesięć lat) i przechodzą na emeryturę w wieku siedemdziesięciu lat (Konstytucja Japonii Art. 79 Par. 5, Prawo sądowe Art. 50). Sędziów sądów niższych instancji mianuje rząd z listy ustalanej przez Sąd Najwyższy (Konstytucja Japonii Art. 80 Par. 1, Prawo sądowe Art. 40 Par. 1). Kadencja sędziów wynosi dziesięć lat, po których to upływie sędziowie mogą zostać ponownie mianowani (Konstytucja Japonii Art. 80 Par. 1, Prawo sądowe Art. 40 Par. 3). Wiek emerytalny sędziów w przypadku sądów krajowych, okręgowych i rodzinnych wynosi 65 lat, sądów do spraw drobnych zaś 70 lat (Konstytucja Japonii Art. 80 Par. 1, Prawo sądowe Art. 50).

Sędziowie wybierani są spośród osób, które mają ukończone studia magisterskie z zakresu prawa oraz zdany egzamin sądowy, tzw. nowy, lub też, jeżeli dana osoba zdała tzw. stary egzamin sądowy, ukończone studium z zakresu sądownictwa w Instytucie Sądownictwa. Dla zapewnienia bezstronności sądów sędziowie obdarzeni są immunitetem i, poza przewidzianą w konstytucji procedurą odwołania sędziego, nie można wbrew ich woli ich

\footnotetext{
${ }^{69}$ Konstytucja Japonii thumaczona po polsku przez prof. Tetsuji Suzuki, wydana przez Ambasadę Japonii w Polsce
} 
zwolnić, przenieść na inne stanowisko lub miejsce, zawiesić lub zmniejszyć ich wynagrodzenie (Konstytucja Japonii Art. 78, Prawo sądowe Art. 48).

Współcześnie problemem sądownictwa japońskiego jest mała liczba sędziów w porównaniu z innymi krajami rozwiniętymi (w 2007 roku 3431 sędziów). Dlatego jeden sędzia zajmuje się rocznie 200-300 sprawami, co prowadzi do przepracowania i psychicznego obciążenia sędziów.

\section{2. 裁判所書記官 saibansho shokikan (Sekretarz sądu)}

Praca sekretarza sądu polega na sporządzaniu i przechowywaniu dokumentacji dotyczacej sprawy oraz udzieleniu pomocy sędziom w sprawdzaniu przepisów prawnych oraz precedensów (Prawo sądowe art. 60).

Konkretnie rzecz biorąc sekretarz sądu dla zapewnienia odpowiedniego przeprowadzenia procedury sądowej sporządza np. protokół zawierający niezbędne punkty ustrukturyzowanych zgodnie z prawem wydarzeń na sali sądowej oraz tytuł egzekucyjny dołączany do wyroku. Protokół sporządzony przez sekretarza sądu jest dokumentem umożliwiającym upublicznienie tego, co działo się na sali rozpraw oraz jedynym dokumentem dowodowym $\mathrm{w}$ tym zakresie.

Ponadto sekretarz sądu dla zapewnienia właściwego i szybkiego przebiegu procesu sądowego współpracuje $\mathrm{z}$ sędzią w zakresie kierowania sprawami sądu. Np. w sprawach cywilnych w razie występowania błędów w tekście pozwu, kieruje pismo do powoda wzywające do ich usunięcia, uzyskuje od stron informacje odnośnie do przedmiotu sporu przed terminem rozprawy, czyni przygotowania zapewniajace sprawny przebieg obrad sądu, przygotowuje pisma pozwalające wyraźnie określić przedmiot sporu w ramach odpowiedniej procedury lub sporządza protokół ustalonego przedmiotu sporu.

Ponadto $\mathrm{w}$ sprawach rodzinnych i dotyczących niepełnoletnich $\mathrm{w}$ zależności od rodzaju i zakresu sprawy bada sprawę i porządkuje zakres sporu z punktu widzenia przepisów prawa. Sekretarz sądu stara się również o odpowiednie rozpatrzenie sporu, np. poprzez staranne objaśnianie procedury sądowej oraz sposobów przedkładania wniosków stronom sporu, które przybyły do budynku sądu.

Jak widać z powyższych przykładów sekretarz sądu na każdym etapie procedury sądowej pełni rozmaite funkcje oparte na jego dużej wiedzy prawnej, odgrywając ważną rolę w zapewnieniu odpowiedniego i szybkiego przebiegu procesu sądowego. Stąd rodzi się potrzeba, by osoby pełniące tę funkcję posiadały znakomite wykształcenie i wysoką kulturę prawna. Dlatego aby zostać mianowanym na sekretarza sądu, należy po zatrudnieniu jako pracownik sądu przejść odpowiednie szkolenie w Instytucie Pracowników Sądowych i zdobyć tam odpowiednią wiedzę.

\section{3. 裁判所速記官 saibansho sokkikan (Stenograf sądowy)}

Stenograf sądowy uczestniczy w posiedzeniu sądu i dokonuje zapisu stenograficznego wypowiedzi stron oraz świadków wygłaszanych przed sądem (Prawo sądowe Art. 60 Par. 2). Jeżeli istnieje potrzeba notowania zeznań in extenso, stenograf uczestniczy 
w rozprawie wraz z sekretarzem sądu i tworzy stenogram. Istnieją różne techniki stenografii, zazwyczaj jednak stenograf posługuje się maszyną stenograficzną zapisując np. zeznania świadków za pomocą symboli itp., a po zakończeniu rozprawy na podstawie scenopisu sporządza stenogram.

\section{4. 裁判所調査官saibansho chōsakan (Inspektor sądowy)}

Inspektorzy sądowi zatrudnieni są w Sądzie Najwyższym, w sądach krajowych i okręgowych, aby na polecenie sędziego przeprowadzać dochodzenie w danej sprawie. Szczególnie w Sądzie Najwyższym inspektorzy odgrywają ważną rolę pomagania sędziom w badaniu przez nich danej sprawy. W sądach krajowych i okręgowych inspektorzy zajmuja się sprawami specjalistycznymi, jak własność intelektualna lub sprawy podatkowe. Inspektorzy sądów rodzinnych różnią się od tych opisanych powyżej i przydzieleni są do sądów rodzinnych i krajowych, prowadząc dochodzenia w sprawach właściwych dla sądów rodzinnych.

\section{5. 検察官kensatsukan (Prokurator)}

Prokuratorzy zajmują się w sprawach karnych m.in. śledztwami, egzekucją wyroków i nadzorem nad ich wykonaniem. Posiadają uprawnienia wnoszenia powództwa z oskarżenia publicznego i domagania się od sądu przeprowadzenia procesu.

W koniecznych przypadkach mogą również wypowiadać się przed sądem. Ponieważ jednak, w przeciwieństwie do policji, prokuratura nie jest instytucją ochrony bezpieczeństwa publicznego, prokuratorzy nie mają uprawnień związanych $\mathrm{z}$ zapobieganiem i ściganiem przestępstw, nie mogą więc, jak policjanci, nosić broni lub przesłuchiwać podejrzanych. W kolokwialnym japońskim prokuratora często określa się terminem $\square \square$ kenji, jest to jednak tylko określenie jednego ze stanowisk prokuratorskich

\section{6. 執行官shikkōkan (dosłownie: „urzędnik egzekwujący”)}

Komornicy działaja przy sądach okręgowych w sądowym postępowaniu egzekucyjnym. Przy egzekucji z nieruchomości przeprowadzają dochodzenie celem stwierdzenia stanu faktycznego oraz procedurę przetargową sprzedaży. Przy egzekucji z ruchomości komornik dokonuje sprzedaży danego przedmiotu, w przypadku zaś egzekucji przymusowej komornik staje się organem dokonującym egzekucji i adresatem odpowiedniego wniosku ze strony wierzyciela. W razie oporu podczas pełnienia obowiązków służbowych komornik może powiadomić osobę stawiającą opór o grożących jej karach lub skorzystać z pomocy policji. 


\section{7. 弁護士bengoshi (Adwokat)}

Adwokaci uczestniczą w procedurach sądowych w zastępstwie stron lub jako ich pomoc prawna. Konkretnie rzecz biorąc, w procedurach prawnych podejmują czynności prawne, jak np. reprezentacja stron w sprawie cywilnej, obrona oskarżonego w sprawie karnej itp. W sprawach cywilnych adwokaci występuja jako reprezentanci procesowi stron, starając się przekonać sąd do swojego stanowiska. W sprawach karnych bronią oskarżonego, by podważyć stanowisko prokuratora i doprowadzić do uniewinnienia swojego klienta. Zazwyczaj osoba biorąca udział w postępowaniu sądowym może czynić to samodzielnie, jednakże ze względu na wielkie skomplikowanie takich procedur, większość osób korzysta z usług adwokata. Aby zostać adwokatem, z zasady trzeba zdać po ukończeniu studiów tzw. egzamin sądowy (jap. 司法試験 shihō shiken) i ukończyć odpowiednie szkolenie. Następnie po wpisaniu na listę adwokatów Japońskiej Izby Adwokackiej i wstapieniu do jednej z pięćdziesięciu dwóch prefekturalnych izb adwokackich można rozpocząć praktykę.

\section{8.後見人 kōkennin (Opiekun)}

Opiekun osób dorosłych to osoba, która pomaga w czynnościach prawnych lub spełnia je w imieniu osoby dorosłej o ograniczonej zdolności prawnej, która nie jest zdolna do samodzielnych decyzji, w celu ochrony owej osoby. Istnieją opiekunowie ustawowi (jap. 法定後見人 hōtei kōkennin), wyznaczani podczas rozprawy sądu rodzinnego, oraz opiekunowie mianowani (jap. 任意後見人 nin’i kōkennin), z którymi osoba podlegająca opiekunce podpisuje umowę, gdy jeszcze może w pełni decydować o sobie samej.

Ściśle rzecz biorąc, opiekunów dzieli się na właściwych opiekunów, doradców (jap. 保佐人 hosanin) i pomocników (jap. 補助人 hojonin). Opiekun wykonuje czynności prawne w imieniu osób, które ze względu na stan zdrowia psychicznego nie są zupełnie w stanie osobiście podejmować decyzji, doradca reprezentuje osoby $\mathrm{z}$ zaburzeniami psychicznymi w znaczącym stopniu ograniczającymi zdolność do podejmowania decyzji, pomocnik zaś wspiera osoby, których zdolność do podejmowania decyzji jest niedostateczna, jednak nie w takim stopniu, jak w poprzednich przypadkach.

\section{9. 裁判員 saiban'in (Sędziowie przysięgli)}

System ławy przysięgłych polega na uczestnictwie w procesie, obok sędziów zawodowych, przysięgłych wybieranych z pomiędzy obywateli (w Japonii formalnie rzecz biorąc ,poddanych”) do każdej z określonej grupy spraw karnych. Odpowiednie przypisy zostały przyjęte w Japonii 21 maja 2004 roku, wprowadzone zaś zostały w życie 21 maja 2009 roku, przy czym sędziowie przysięgli rozpoczęli pracę w sądach w trzeciej dekadzie lipca. Sędziowie przysięgli mają brać udział w procesach przed sądami okręgowymi w poważnych sprawach karnych: o zabójstwo, zranienie powodujące 
śmierć, zabójstwo $\mathrm{w}$ związku $\mathrm{z}$ rozbojem, podpalenie, porwanie (Ustawa dotycząca udziału sędziów przysięgłych w sprawach karnych Art. 3). Z zasady kolegium sędziów składać się będzie $z$ trzech sędziów zawodowych i sześciu sędziów przysięgłych lub z jednego sędziego zawodowego i czterech sędziów przysięgłych (Art. 2, Par. 2-3).

Powyższy system został wprowadzony jako element reformy systemu sądownictwa. Poprzez udział członków społeczeństwa w sprawach karnych proces sądowy ma stać się mu bliższy i łatwiejszy do zrozumienia, co z kolei ma doprowadzić do wzrostu zaufania obywateli dla systemu sądownictwa. Podobne systemy lawy przysięgłych występują również w Stanach Zjednoczonych i Wielkiej Brytanii (jap. 陪審制 baishinsei) oraz w krajach europejskich, jak Włochy i Niemcy (jap. 参審制 sanshinsei). System ławy przysięgłych $\mathrm{w}$ wersji zbliżonej do anglosaskiej funkcjonował w Japonii przed II wojna światowa, ale został zawieszony w 1943 roku. Główne różnice między systemem japońskim a innymi polegają na tym, że ławy przysięgłych w Stanach Zjednoczonych i Wielkiej Brytanii sa wybierane do jednej sprawy $i$ rola ich polega wyłącznie na stwierdzeniu stanu faktycznego (czy oskarżony jest winny, czy nie). System włosko-niemiecki jest kadencyjny, zaś sędziowie przysięgli poza stwierdzeniem stanu faktycznego biorą również udział w ustalaniu wymiaru kary. System japoński jest rodzajem syntezy obu tych modeli. Sędziowie przysięgli będą wybierani do każdej sprawy i będą ustalali winę oskarżonego oraz brali udział $\mathrm{w}$ określeniu wymiaru kary. Jednym $\mathrm{z}$ celów takiego rozwiązania jest również dążenie do naśladowania krajów rozwiniętych, z których coraz więcej wprowadza u siebie podobne modele.

Problemem jednak staje się przyjęta procedura, zgodnie z którą kandydatów na sędziów przysięgłych wzywa się losowo bez względu na ich wolę. Innymi słowy, jeżeli nie wystapią pewne ograniczone $\mathrm{w}$ liczbie przyczyny bezpośrednie, stawienie się w sądzie będzie przymusowe, osoby zaś, które w sądzie się nie pojawią, zapłacą karę do stu tysięcy jenów. Bezpośrednie przyczyny, o jakich tu mowa, to: 1. brak zdolności (nieukończenie obowiązkowej edukacji, skazanie na karę pozbawienia wolności i większą, Art. 14); 2. zakaz ze względu na sprawowaną funkcję (np. pewna grupa pracowników sektora publicznego, osoby związane $\mathrm{z}$ wymiarem sprawiedliwości, policjanci, Art. 15); 3. nieodpowiedniość ze względu na związek ze sprawą (osoby związane z oskarżonym lub poszkodowanym, osoby uczestniczące w sprawie itp., Art. 17); 4. rezygnację (np. osoby powyżej 70 roku życia, uczniowie i studenci, osoby, które ostatnio pełniły funkcję sędziego przysięgłego, osoby ciężko chore lub zajmujące się opieką lub kształceniem członków rodziny, Art. 16).

Podnoszą się głosy, iż przymusowość w przypadku braku zaistnienia jednej z powyższych pięciu okoliczności, jest ,pracą przymusową wbrew woli społeczeństwa”, sprzeczną z Art. 18 konstytucji („Nikt nie może być trzymany w poddaństwie jakiegokolwiek rodzaju. Przymusowe roboty są zakazane, z wyjątkiem gdy stanowią karę orzeczoną za przestępstwo".) Ponadto choć celem, jak wspomniano powyżej, ma być również zmniejszenie dystansu między społeczeństwem a wymiarem sprawiedliwości, to trudność i skomplikowanie prawa w Japonii, znacznie bardziej odległego od doświadczenia codziennego niż w innych krajach, powoduje niepokój wśród Japończyków, iż będą oni pytani o rzeczy, o których nie mają pojęcia. Powoduje to, iż 
nie jest to rozwiązanie pożądane przez społeczeństwo. Inne głosy krytyki wskazują na fakt, że w Japonii istnieje kara śmierci i w sprawach, w których orzeczenie tej kary musi być brane pod uwagę, obciążenie sędziów przysięgłych będzie bardzo duże.

\section{Sprawy podlegające rozstrzygnięciom w sądach w Japonii}

W Japonii sądy zajmują się pięcioma rodzajami spraw według prawa japońskiego: cywilnymi (jap. 民事事件 minji jiken), administracyjnymi (jap. 行政事件 gyōsei jiken), karnymi (jap. 刑事事件 keiji jiken), rodzinnymi (jap. 家事事件 kaji jiken) oraz dotyczącymi nieletnich (jap. 少年事件 shōnen jiken). Sprawy cywilne są procedurą mającą na celu rozwiązywanie sporów prywatnych między osobami fizycznymi. Sprawy administracyjne $\mathrm{z}$ kolei to procedury rozpatrywania sporów, w których stroną jest państwo, organy lokalnej administracji publicznej lub inne instytucje publiczne. W sprawach karnych sądy nakładają grzywny, kary więzienia lub inne wobec osób, które dopuściły się czynu niezgodnego $\mathrm{z}$ prawem karnym. Sprawy rodzinne dotyczą rozwiązywania sporów w rodzinach, te zaś, które dotyczą osób niepełnoletnich są procedurą karania osób niepełnoletnich, które złamały przepisy prawa karnego lub inne. Głównie chodzi tu o kradzieże, oszustwa, kradzieże z włamaniem, pobicie z obrażeniem ciała, jazdę samochodem bez ważnego prawa jazdy oraz pod wpływem alkoholu. Poniżej przedstawione zostaną szczegółowe informacje dotyczące spraw cywilnych.

\subsection{Sprawy cywilne}

\subsubsection{Rodzaje spraw cywilnych}

Ze względu na charakter rozróżnia się sześć rodzajów postępowań cywilnych:

a. 民事調停事件 minji chōteijiken (mediacje cywilne) - jest to postępowanie ustanawiające podstawy do rozwiązania sporu w oparciu o ugodę stron. Celem procedury jest rozwiązanie konfliktu poprzez wzajemną rozmowę za pośrednictwem sądu. Również w przypadku zakończenia sprawy w wyniku mediacji, jeżeli ugoda osiagnięta $\mathrm{w}$ jej trakcie nie jest wcielona w życie, można doprowadzić do jej przymusowej egzekucji w trybie tzw. procedury cywilnej.

b. 民事訴訟事件 minji soshōjiken (sprawy z powództwa cywilnego) - jest to podstawowa procedura rozpatrywania sporów cywilnych, w której sąd wydaje przymusowe orzeczenie bez względu na zgodę stron. Sprawy te $\mathrm{z}$ zasady rozpatrywane są podczas rozprawy sądowej. Na przykład do takich spraw należy domaganie się zwrotu należności finansowej. Osoba wnioskująca o zwrot, powód (jap. 原告 genkoku), oraz osoba pozwana (jap. 被告 hikoku) przedstawiają swoje stanowiska, a następnie sędzia wydaje wyrok (jap. 判決 hanketsu) po przebadaniu owych stanowisk, w oparciu o nie oraz materiał dowodowy. Wyrok zostaje wydany na podstawie opinii sędziego, nawet jeżeli zeznania stron i materiał dowodowy 
przedstawiony przez nie są sprzeczne. Jeżeli wyrok ów się uprawomocni, zarówno powód jak i pozwany zmuszeni są do jego przestrzegania. Jeżeli uznano zasadność wniosków powoda, a pozwany nie stosuje się do wyroku, wówczas można dokonać przymusowej egzekucji roszczeń powoda. Rozprawy zajmujące się takimi sprawami z zasady są otwarte i każdy może się im przysłuchiwać. W zależności od sprawy, jeżeli za pośrednictwem sądu dojdzie do zawarcia między powodem a pozwanym porozumienia, dochodzi do ugody (jap. 和解 wakai), która poprzez spisanie w postaci odpowiedniej umowy kończy sprawę. Również w przypadku zakończenia sporu w takiej formie, jeżeli postanowienia ugody nie są wypełniane, można doprowadzić do ich realizacji na drodze egzekucji cywilnej. Sprawy z powództwa cywilnego dzielą się z grubsza na trzy rodzaje:

ii-i) 通常訴訟 tsūjō soshō (sprawa zwykła) np. zwrot pożyczki lub opuszczenie nieruchomości, odszkodowanie $\mathrm{z}$ tytułu szkody osobowej, spory prawne między osobami fizycznymi.

ii-ii) 手形小切手訴訟 tegata kogitte soshō (sprawy dotyczące weksli i czeków) Sprawy, w których na podstawie specjalnych przepisów cywilnego prawa procesowego powód wnosi o spłatę weksla lub czeku. Powód ma prawo wyboru między trybem zwykłym a trybem a-b.

ii-iii) 小額訴訟 shōgaku soshō (sprawy, w których przedmiot sporu warty jest małej sumy pieniężnej, odpowiedni po polsku „sprawy drobne”) - Sprawy, których przedmiotem jest zapłata sumy do 600 tysięcy jenów, rozpatrywane w szybkiej i uproszczonej procedurze przez sąd do spraw drobnych.

c. 人事訴訟事件 jinji soshō jiken (sprawy dotyczące osobowego statusu prawnego) Przedmiotem spraw dotyczących osobowego statusu prawnego są spory między jednostkami, takie jak np. rozwód lub uznanie ojcostwa. Zasadniczo przed wniesieniem pozwu rozpatrywanego jak wszystkie inne sprawy cywilne, należy złożyć wniosek o mediacje rodzinną do sądu rodzinnego, gdzie sprawa traktowana jest jako rodzinna. Mediacja jest próbą porozumienia stron za pośrednictwem sądu; czynione są starania, by tego rodzaju kwestie, jak rozwód lub uznanie ojcostwa, dotyczące osobowego statusu prawnego, rozpatrywane były na takiej właśnie drodze.

d. 民事執行事件 minji shikkōjiken (egzekucja cywilna) - Jeżeli dana osoba nie wykonuje orzeczenia sądu zgodnie $\mathrm{z}$ wyznaczonymi przezeń warunkami, można przeprowadzić procedurę przymusowej egzekucji cywilnej. Decyzja sądu realizowana jest w oparciu o tekst orzeczenia sadu, umowę ugody lub protokół mediacji, poprzez np. zajęcie ruchomości pozwanego, jak samochód lub nieruchomości (grunty lub budynki), sprzedanie ich i pokrycie z uzyskanych środków należności lub poprzez zajęcie pensji pozwanego i odciaganie z niej sum $\mathrm{w}$ zasądzonej wysokości.

e. 民事保全事件 minji hōzenjiken (zabezpieczenie cywilne) - W przypadku wystapienia okoliczności uniemożliwiających realizację praw osobistych w razie 
braku szybkiego rozwiązania sporu prywatnego, można skorzystać z procedury zabezpieczenia cywilnego, pozwalającej na przygotowanie w sądzie podstaw do rozwiązania sporu oraz na ich przymusową egzekucję. Przykładowo można mieć do czynienia z sytuacja, w której sędzia uznaje przypuszczenie zgodności (jap. 疎明 somei) ze stanem faktycznym zeznań pożyczkodawcy dotyczących pożyczki i wydaje szybko w oparciu o nie wyrok, po czym nakazuje tymczasowe zajęcie nieruchomości dłużnika.

f. 倒産事件 tōsan jiken (upadłość) - Jest to procedura przeprowadzana w przypadku osób fizycznych lub osób prawnych prowadzących działalność handlową, które są niewypłacalne. Procedura ta ma dwa rodzaje: procedura likwidacyjna (jap. 清算型 seisangata) i procedura restrukturyzacyjna (jap. 再建型 saikengata). Procedura likwidacyjna polega na spieniężeniu majątku i zaspokojeniu roszczeń wszystkich wierzycieli, procedura restrukturyzacyjna zaś na kontynuowaniu działalności gospodarczej w oparciu o majątek dłużnika i zaspokajaniu roszczeń wierzycieli z zysków uzyskiwanych tą drogą. Jeżeli dłużnik nie może zwrócić wierzytelności, np. pożyczek, wierzycielom z całego swojego majątku, na wniosek dłużnika i wierzycieli wydaje się wierzycielom decyzje o rozpoczęciu procedury upadłościowej, wyznaczony zaś przez sąd syndyk (zazwyczaj prawnik) równomiernie spłaca wierzycieli, dokonując spieniężenia majątku dłużnika. W przypadku osoby nie posiadającej majątku procedura sądowa kończy się na wydaniu orzeczenia o rozpoczęciu procedury upadłościowej.

\subsubsection{Nazewnictwo stron procesowych}

W sprawach cywilnych w zależności od rodzaju sprawy różni się nazewnictwo stron (pozywającej i pozwanej). Poniższa tabela zawiera ich zestawienie.

\begin{tabular}{|l|l|l|}
\hline Rodzaj sprawy & Strona pozywająca & Strona pozwana \\
\hline \hline Mediacja & $\begin{array}{l}\text { 申立人 mōshitatenin } \\
\text { (pol. pozywający) }\end{array}$ & $\begin{array}{l}\text { 相手方 aitekata } \\
\text { (pol. pozwany) }\end{array}$ \\
\hline \hline $\begin{array}{l}\text { Sprawy z powództwa } \\
\text { cywilnego }\end{array}$ & $\begin{array}{l}\text { 原告 genkoku } \\
\text { (pol. powód) }\end{array}$ & $\begin{array}{l}\text { 被告 hikoku } \\
\text { (pol. pozwany) }\end{array}$ \\
\hline Egzekucja & $\begin{array}{l}\text { 債権者 saikensha } \\
\text { (pol. wierzyciel) }\end{array}$ & $\begin{array}{l}\text { 債務者 saimusha } \\
\text { (pol. dłużnik) }\end{array}$ \\
\hline Zabezpieczenie & $\begin{array}{l}\text { 債権者 saikensha } \\
\text { (pol. wierzyciel) }\end{array}$ & $\begin{array}{l}\text { 債務者 saimusha } \\
\text { (pol. dłużnik) }\end{array}$ \\
\hline Upadłość & $\begin{array}{l}\text { 申立人 mōshitatenin } \\
\text { (pol. pozywający) }\end{array}$ & $\begin{array}{l}\text { 被申立人 himōshitatenin } \\
\text { (pol. pozwany) }\end{array}$ \\
\hline
\end{tabular}


Yuki HORIE, System sqdownictwa cywilnego w Japonii.

Ponadto w sprawach innych niż cywilne stosuje się następujące nazewnictwo stron:

\begin{tabular}{|l|l|l|}
\hline Rodzaj sprawy & Strona pozywająca & Strona pozwana \\
\hline \hline $\begin{array}{l}\text { Sprawy } \\
\text { administracyjne }\end{array}$ & $\begin{array}{l}\text { 原告 genkoku } \\
\text { (pol. powód) }\end{array}$ & $\begin{array}{l}\text { 被告 hikoku } \\
\text { (pol. pozwany) }\end{array}$ \\
\hline Sprawy karne & $\begin{array}{l}\text { 検察側 kensatsugawa } \\
\text { (pol. oskarżyciel) } \\
\text { (dosłownie: strona } \\
\text { prokuratora) }\end{array}$ & $\begin{array}{l}\text { 被告人 hikokunin } \\
\text { (pol. oskarżony) }\end{array}$ \\
\hline Sprawy rodzinne & $\begin{array}{l}\text { 申立人 mōshitatenin } \\
\text { (pol. pozywający) }\end{array}$ & $\begin{array}{l}\text { 事件本人 jiken hennin } \\
\text { (pol. pozwany) } \\
\text { (dosłownie: „osoba bezpośrednio } \\
\text { związana z daną sprawą) }\end{array}$ \\
\hline $\begin{array}{l}\text { Sprawy dotyczące } \\
\text { nieletnich }\end{array}$ & $\begin{array}{l}\text { 検察官 kensatsukan } \\
\text { (pol. prokurator) }\end{array}$ & $\begin{array}{l}\text { 少年 shōnen } \\
\text { (pol. młodociany) }\end{array}$ \\
\hline
\end{tabular}

Należy zwrócić uwagę na różnicę między „pozwanym” (jap. 被告 hikoku) a „oskarżonym” (jap. 被告人 hikokunin). Te dwa terminy japońskie różni jedynie dodanie do ogólnego hikoku, dosłownie „tego, który został pozwany” w przypadku pozwanego, sufiksu - 人-nin, „człowiek” w przypadku oskarżonego. Hikoku w sprawach cywilnych jest strona, która jest przedmiotem wniosku powoda, hikokunin zaś to osoba, która złamała przepisy prawa karnego i, w związku z tym, może zostać ukarana. Chociaż oba te słowa są bardzo podobne, różni je bowiem jedynie obecność ideogramu -nin, „człowiek”, oba wskazują na osobę i w mowie potocznej traktowane są zamiennie. Powoduje to, iż wielu ludzi błędnie uważa, iż powód w procesie cywilnym, hikoku, jest osobą, która popełniła przestępstwo.

\section{Ważne terminy dotyczące postępowań cywilnych}

Poniżej następuje wyjaśnienie kilku ważnych terminów z zakresu procedur cywilnych:

《私的自治の原則》 shiteki jichi no gensoku ,zasada samostanowienia” - Proces sądowy rozpoczyna się na skutek przedłożenia odpowiedniego wniosku (np. pozew) przez stronę pozywającą i może zostać zakończony przez wycofanie go przez nią. Przedmiotem sprawy są tylko te kwestie, które zostały objęte we wniosku procesowym.

《職権進行主義》 shokken shinkō shugi; dosł: „Zasada prowadzenia [przez osobę] uprawnioną z racji sprawowanej funkcji” (zasada wiodącej roli sędziego) - Prosto rzecz ujmując jest to zasada, iż sprawy cywilne prowadzone są przez sędziego. Sądowi przedkładany jest wniosek $\mathrm{i}$, jeżeli uznany zostanie za formalnie poprawny, sąd wyznacza termin rozprawy, dostarcza pozwanemu pozew wraz $\mathrm{z}$ wezwaniem. Za formułowanie stanowiska procesowego oraz przedstawianie dowodów odpowiedzialne sa 
strony, ale jeżeli stanowisko procesowe strony będzie niejasne, sąd może je objaśniać, domagać się uzupełnienia materiału dowodowego, a czasami również doradzać zawarcie ugody.

《弁論主義》 benronshugi „Zasada orzekania” - Stanowisko procesowe oraz dowody go dotyczace związane ze stanem faktycznym będącym podstawą do wydania wyroku prezentowane są przez strony. Za przedstawienie faktów uzasadniających roszczenia powoda odpowiedzialny jest powód, za ich podważenie pozwany.

《処分権主義》 shobunkenshugi „zasada prawa do załatwienia sprawy” - W przypadku sprawy z powództwa cywilnego może ona zakończyć się na drodze ugody między stronami, wycofania roszczeń przez powoda, uznania roszczeń przez pozwanego lub wycofania powództwa przez powoda. Zasada ta oznacza, że decyzję o sposobie rozwiązania sporu między stronami oraz zakończenia sprawy podejmują strony.

《擬制自白》 gisei jihaku „wyrok zaoczny” - W przypadku, gdy mimo przyjęcia wezwania wystosowanego przez sąd dana osoba nie pojawiła się celem złożenia zeznań bez przedłożenia żadnego dokumentu, z zasady uznaje się to za potwierdzenie stanu faktycznego opisanego w pozwie, będącego podstawą dla uzasadnienia roszczeń powoda.

《小額訴訟》 shōgakusoshō „W sprawach drobnych do 600 tysięcy jenów” - Sprawy, w których przedmiotem roszczenia jest suma mniejsza od 600 tysięcy jenów, rozpatrywane są $\mathrm{z}$ zasady podczas jednego posiedzenia sądu, wyrok zaś wydawany jest tego samego dnia. Od takiego wyroku nie przysługuje apelacja do sądu wyższej instancji, można jedynie nie zgodzić się z wyrokiem. W takim wypadku pozwany zmuszony jest skorzystać ze standardowej procedury cywilnej.

《支払督促》 shiharai tokusoku „postępowanie upominawcze” - Jest po pismo sporządzane $\mathrm{w}$ specjalnej procedurze nazywanej postępowaniem upominawczym przez sąd do spraw drobnych, odpowiadające „wyrokowi” w procedurze standardowej. Ponaglenie zapłaty jest postępowaniem ułatwiającym wierzycielowi szybkie i proste oraz tanie uzyskanie oficjalnej decyzji sądu. W procedurze tej sekretarz sądu sporządza ponaglenie zapłaty na podstawie wniosku wierzyciela bez badania jego zgodności ze stanem faktycznym. Jeżeli w ciagu dwóch tygodni od przesłania ponaglenia dłużnikowi nie przedłoży on pisemnego zażalenia na tę decyzję sądu, sekretarz sądu może wydać tymczasową deklarację egzekucji. Wierzyciel na podstawie oryginału ponaglenia i dowodu przesłania jego kopii dłużnikowi może złożyć wniosek o przymusową egzekucję. Ponaglenie zapłaty $\mathrm{z}$ tymczasową deklaracją egzekucji zostaje wysłane dłużnikowi. Jeżeli w ciagu dwóch tygodni od jego przesłania dłużnik nie przedłoży zażalenia, ponaglenie zapłaty uprawomocnia się i posiada moc prawną równą uprawomocnionemu wyrokowi sądu. (Na skutek nowelizacji Kodeksu Cywilnego, która zeszła w życie 1 kwietnia 2005 roku możliwe jest wnioskowanie o sporządzenie ponaglenia zapłaty poprzez internet). 


\section{Przebieg sprawy cywilnej}

Proces cywilny ma na celu rozwiązywanie sporów prawnych osób fizycznych i prawnych. Proces rozpoczyna wniesienie pozwu (jap. 提訴 teiso) przez powoda. Pozwany odpowiada nań (jap. 応訴 ōso) i broni swojego stanowiska.

\subsection{Wniesienie pozwu}

Powód (lub jego pełnomocnik) przekazuje najpierw pozew (jap. 訴状 sojō) oraz dokumentacje dowodowa (jap. 証拠書類 shōko shorui) właściwemu sądowi. Przy pisaniu pozwu trzeba stosować się do wymagań, jakie tego rodzaju pismom stawia prawo. W treści pozwu należy określić przedmiot roszczenia oraz jego uzasadnienie. Ponieważ niewłaściwie sporządzony pozew nie zostanie przyjęty, osoby nie posiadające wiedzy prawniczej zmuszone są do skorzystania z usług adwokata. Ponadto, ponieważ w przypadku rozpraw cywilnych nie ma przymusu reprezentacji procesowej oraz thumaczenia sądowego, jeżeli dojdzie się do wniosku, że skorzystanie $\mathrm{z}$ usług prawnika lub thumacza będzie korzystne, należy wynając ich we własnym zakresie. Oczywiście możliwe jest samodzielne występowanie przed sądem, ale powszechnie uważa się za korzystne zatrudnienie prawnika i udzielenie mu pełnomocnictwa (jap. 全権代理 zenken dairi). Dokumentacja dowodowa oznacza tu teksty umów, wypisy z księgi wieczystej itp. dokumenty będące obiektywnym potwierdzeniem roszczeń powoda. Roszczenie nieudokumentowane podlega oddaleniu. Pozew oraz dokumentację dowodową należy przygotować w trzech kompletach, $\mathrm{z}$ których jeden pozostawia się sobie, a pozostałe przedkłada się sądowi po opłaceniu odpowiedniej opłaty skarbowej. $Z$ nich jeden zatrzymuje sąd (tzw. egzemplarz główny), jeden zaś otrzymuje pozwany (tzw. kopia). Prawo przewiduje wła-ściwość sądu (jap. 管轄 kankatsu); zazwyczaj jest to właściwy sąd w miejscu zamie-szkania powoda.

\subsection{Odpowiedź na pozew}

Pozew oraz dokumentacja złożone przez powoda zostają przesłane listem poleconym. Jeżeli pozew zostanie zignorowany, sąd uzna wszystkie roszczenia powoda, dlatego też z zasady trzeba odpowiedzieć na pozew. Wydanie niekorzystnego wyroku dla powoda ze względu na zignorowanie przezeń pozwu nazywa się ,wyrokiem [przy] nieobecności” (jap. 欠席判決 kesseki hanketsu). W odpowiedzi na pozew pozwany sporządza pisemną „obronę” (jap. 答弁書tōbensho). Jeżeli ponadto dysponuje dowodami wspierającymi jego stanowisko, dołącza je. Dokumenty te nazywa się kontrdowodami (jap. 反証 hanshō). Ponadto ponieważ pierwsza rozprawa planowana jest $\mathrm{w}$ terminie dogodnym wyłącznie dla sądu i powoda, pozwany po przedłożeniu pisemnej odpowiedzi na pozew może tylko w tym przypadku nie stawić się na rozprawie. Od kolejnej rozprawy obowiazuje go obecność. W przypadku nieobecności pozwanego mimo przyjęcia wezwania wystosowanego przez sąd, z zasady uznaje się to za potwierdzenie stanu faktycznego opisanego w pozwie. 


\subsection{Rozprawa - Rozpatrzenie pozwu}

Sąd najpierw bada pozew pod względu formalnym i jeżeli ten nie ma uchybień formalnych wyznacza termin rozprawy sądowej i wzywa strony do uczestnictwa w niej. Jeżeli pozew ma uchybienia, sędzia poleca powodowi ich usunięcie.

\subsection{Rozprawa - Przesłuchanie stron}

W sądzie w trakcie otwartej dla publiczności rozprawy następuje wysłuchanie stron. $\mathrm{W}$ sądzie do spraw drobnych $\mathrm{z}$ zasady rozprawę przeprowadza jeden sędzia, w sądzie okręgowym jednoosobowe lub trzyosobowe kolegium sędziowskie, w sądzie krajowym z zasady trzyosobowe kolegium sędziowskie. Na rozprawie stawia się powód lub też pełnomocnik i przed przedstawieniem stanowiska procesowego przekłada dowody oparte na przedłożonej dokumentacji. Jeżeli stanowisko strony i treść dokumentów są sprzeczne, sędzia przewodniczący może zażądać złożenia dodatkowych wyjaśnień.

Zazwyczaj pierwsza rozprawa kończy się po ok. 15 minutach. Ponieważ podczas rozprawy nie ma możliwości ustnego przedstawienia swojego stanowiska, przedstawia się je zazwyczaj wcześniej w formie pisemnej. Nazywa się je „pismami wstępnymi” (jap. 準備書面 jumbi shomen). procedur.

Najpierw ustala się przedmiot sporu za pomocą jednej z trzech poniższych

i) Przesłuchanie wstępne (jap. 準備的口頭弁論 jumbiteki kōtō benron) - odbywa się podczas publicznej rozprawy, można przedsięwziąć wszelkie kroki, jakich wymaga przedmiot sporu.

ii) Wstępna procedura orzecznictwa (jap. 弁論準備手続き benron jumbi tetsuzuki) - Odbywa się w pokoju innym niż sala rozpraw i nie musi być upubliczniona. Jeżeli strona mieszka daleko od sądu i nie może się w nim stawić, wykorzystuje się np. połączenie telefoniczne lub konferencyjne.

iii) Procedura pisemna (jap. 書面による手続き shomen ni yoru tetsuzuki) - Jeżeli strona nie stawia się na rozprawie, może ustalić przedmiot sporu np. poprzez złożenie pism wstępnych. Jeżeli jest taka konieczność można przedyskutować przedmiot sporu z wykorzystaniem np. połączenia telefonicznego.

\subsection{Rozprawa - Sprawdzenie dowodów}

W momencie, w którym przedmiot sporu został jasno ustalony, sąd, w celu wydania orzeczenia w zakresie owego przedmiotu, przeprowadza analizę dowodów, wysłuchuje zeznań świadków i stanowisk stron. Procedurę tę nazywa się „sprawdzeniem dowodów” (jap. 証拠調べ shōkoshirabe). Z zasady przesłuchiwanie następuje w kolejności: powód, pozwany i świadkowie, jednakże w japońskim prawie nie ma przepisów ściśle ja ustalających, decyzje zaś w tym zakresie, aż do ustalenia stanu faktycznego i jego zgodności z materiałem dowodowym, powierzone są sędziemu. 


\subsection{Rozprawa - Protokół rozprawy przesłuchania stron}

Zwie się tak protokół sporządzany przez sędziego dokonującego przesłuchania (jap. 口頭弁論調書 kōtō benron chōsho). Poza wypowiedziami stron, świadków, biegłych $\mathrm{i}$ innych $\mathrm{z}$ sali rozpraw, wpisane są weń stanowiska stron oraz przedłożony materiał dowodowy. Podpisuje go i umieszcza na nim swoją pieczęć sekretarz sądu, sędzia zaś zatwierdza. W rozprawie poza sekretarzem sądu uczestniczy stenograf.

\subsection{Zakończenie rozprawy}

W pierwszym rzędzie celem sądu jest doprowadzenie do ugody. Ugoda oznacza zakończenie procesu w jego trakcie poprzez kompromis stron bez konieczności wydawania wyroku (jap. 判決 hanketsu) przez sędziego. W przeciwieństwie do wyroku nie ma ona powagi rzeczy osądzonej, nie można też odwołać się od niej. W wyroku z kolei sędzia orzeka o roszczeniach stron. Wyrok zostaje wygłoszony ustnie oraz przekazany pisemnie. W tekście wyroku zawarta jest część główna, stanowiska stron oraz uzasadnienie. Zostaje on przekazany stronom zaraz po odczytaniu ${ }^{70}$.

\subsection{Odwołanie się od wyroku}

Jeżeli strona nie jest zadowolona $\mathrm{z}$ wyroku, w ciagu czternastu dni od jego ogłoszenia może odwołać się do sądu krajowego. Ponieważ rozprawa odwoławcza uznawana jest za ciąg dalszy procesu w sądzie pierwszej instancji, w przypadku nieprzedstawienia nowych dowodów rzadko dochodzi do obalenia wyroku sądu pierwszej instancji. Od tego wyroku można odwołać się do sądu wyższej instancji. Sąd odwoławczy wyższej instancji przeprowadza analizę zagadnienia prawnego i $\mathrm{z}$ zasady jest ograniczony stanem faktycznym stwierdzonym w pierwszym wyroku.

\subsection{Koszt procesowe}

Zasadniczo koszty procesowe ponosi strona przegrana. Sa to np. koszty znaczków skarbowych niezbędnych przy składaniu pozwu, opłaty pocztowe, koszty podróży świadków itp. Koszty procesowe nie obejmują jednak kosztów reprezentacji stron. Aby zabezpieczyć możliwość korzystania z sądownictwa przez osoby, których nie stać na pokrywanie takich kosztów, istnieje system zawieszania ich spłaty, a także zwolnienie od tych kosztów. Nazywa się go ,pomocą procesową” (jap. 訴訟上の救助soshōjō no kyūjo).

\footnotetext{
${ }^{70}$ Oprócz 判決 hanketsu (orzeczenie), istnieje również 決定 kettei (decyzja) i 命令 meirei (nakaz). Sa one wydawane gdy jest wymagana szybka decyzja w przypadku egzekucji cywilnej, zabezpieczenia cywilnego i upadłości. 決定 kettei jest wydawane przez sąd, a 命令 meirei jest wydawane przez sędziego.
} 


\section{Zakończenie}

Ogólnie rzecz ujmując, termin „sąd najwyższy” w thumaczeniu na japoński brzmi 最高裁判所 saikō saibansho, „sędzia” - 裁判官 saibankan, ,postępowanie cywilne” zaś jako 民事訴訟 minji soshō. Jednakże szczegółowa analiza desygnatów tych wyrażeń prowadzić musi do wysunięcia wniosku, iż znaczenie terminów i funkcje jakie pełnią w języku prawnym i prawniczym różnią się w obu krajach. Ponieważ dla osoby posługującej się słownictwem prawnym, a szczególnie thumacza ustnego i pisemnego, nawet niewielkie różnice w polach znaczeniowych miedzy dwoma językami mają niezwykle duże, kluczowe wręcz znaczenie, bardzo istotne jest uchwycenie znaczenia przekładanego na drugi język terminu. 


\section{Bibliografia}

Aizawa, Sachno 相沢幸夫. 1987. Hōritsu yōgo taiyakushū 法律用語対訳. Tokio: Shōji hōmu kenkyūkai商事法務研究会.

Furuta ， Hiroharu古田裕清. 2005. Honyaku go to shiteno nihon no hōritsu $y \bar{o} g o$ 翻訳語としての日本の法律用語. Tokio: Chūō shuppanbu 中央出版部. Hashiuchi, Takeshi橋内武, Hotta, Shūgo堀田秀吾 (eds.) 2012. Hō to gengo法と言語. Tokio: Kuroshio shuppan くろしお出版.

Hoshino, Eiichi 星野英一. 1998. Minpō no susume民法のすすめ. Tokio: Iwanami shodo 岩波書房.

Kielar, Barbara, Z. 1988. Ttumaczenie i koncepcje translatoryczne, Wrocław: Ossolineum.

Kierzkowska, Danuta. 2008. Tłumaczenie prawnicze, Warszawa: Translegis.

Matsumura, Hiroshi 松村弘. 2003. Hōtei tsūyaku 法廷通訳. Tokio: Kokusai tsūyaku gōshi geisha 国際通訳合資会社.

Matulewska, Aleksandra. 2007. Lingua Legis in Translation, Amsterdam: Peter Lang Publishing House.

Ōmura, Atsushi 大村敦. 2001. Kihon minpō 基本民法. Tokio: Yūhikaku 有斐閣.

Snobe, Atsushi 園部厚. 2005. Saibansho no koto ga subete wakaru hon

裁判所のことがすべて分かる本. Tokio: Minjihō kenkyūkai民事法研究会.

Sotoyama, Shigehiko 外山滋彦. 1976. Nihongo no kosei日本語の個性. Toki: Chūō kōronsha 中央公論社.

Suzuki, Takao 鈴木孝夫. 1973. Kotoba to bunka 言葉と文化. Tokio: Iwanami shinsho 岩波書房.

Suzuki, Takao 鈴木孝夫. 1996. Nihongo to gaikokugo 日本語と外国語. Tokio: Iwanami shoten 岩波書店.

Watanabe, Osamu 渡辺修, Nagao, Hiromi 長尾ひろみ, Mizuno, Makiko 水野真木子. 2004. Shihō tsūyaku 司法通訳. Tokio: Shōhakusha 松柏社.

Yokoi, Hideak i横井秀明. 2007. Jitsuyōban hōritsu yōgo no kisochishiki 実用版法律用語の基礎知識. Tokio: jiyū kokuminsha 自由国民社. 
